\title{
DIE WARE KERK EN 'N VALSE KERK
}

Mens mag jou van die Kerk nie afskei nie.

In Hebreëers 11 vers 1 vind ons die klassieke definisie van wat geloof is. Dit word daar omskryf as 'n vaste vertroue op die dinge wat ons hoop, as 'n bewys van die dinge wat ons nie sien nie. Vir die Roomse teologie is hierdie definisie 'n struikelblok en 'n dwaasheid. Rome wil nie deur geloof wandel nie maar deur aanskouing. Rome wil sien. Die opgevare Heer en Heiland, die onsigbare Hoof van die Kerk moet volgens Rome hier sigbaar aanwesig wees, sigbaar deur die biskop van Rome wat Hom sigbaar verteenwoordig, sigbaar deur die brood en wyn wat in die avondmaal ophou om brood en wyn te wees en in die liggaam en bloed van Christus verander. Die geloof het dan ook vrywel geen plek by Rome nie.

Die Reformatore het weer baie sterk op die geloof die nadruk gelê en veral op die persoonlike geloof. Die waaragtige protestant weet dan ook dat hy hier op aarde ' $n$ vreemdeling en 'n bywoner is wat in die geloof wandel en nie deur die aanskouing nie. Maar hierdie persoonlike geloof is nie as 'n blote individualistiese verhouding tussen God en mens voorgestel nie. Nee, die Reformatore en met name Calvyn, het beklemtoon dat hierdie verhouding nie ingedink kan word tensy op die onsigbare sowel as op die sigbare kant van die Kerk die nadruk gelê word nie. Rome maak geen onderskeid tussen die sigbare en die onsigbare Kerk nie maar ken alleen die sigbare Kerk met die pous, die sigbare verteenwoordiger van Christus op aarde as die Hoof. 
Die Protestantisme ken ook maar slegs een Kerk, een heilige algemeen Christelike Kerk, en hierdie Kerk word nie in twee dele geskei nie, 'n sigbare en ' $n$ onsigbare deel, maar word in twee kante onderskei, 'n sigbare en 'n onsigbare kant. En van hierdie Kerk sê die Protestant dit aan Cyprianus na: Salus extra ecclesiam non est, buite die Kerk is geen saligheid nie. Calvyn beklemtoon dit in sy bekende Institutio. Die Kerk is onse moeder wat ons in haar skoot ontvang. ons deur haar borste voed en ons onder haar bewaring en opsig beskerm totdat ons ons sterflike vlees afgelê het en aan die Engele gelyk is. Buite die skoot van die Kerk is ook geen vergewing van sonde of enige redding te wagte nie.)

Hierdie Kerk word alleen deur die uitwendige prediking en verkondiging van Gods woord opgehou en die enigste band waardeur die gelowiges onderling saamgebind word, is die eendragtelike onderhouding en bevordering van die verordeninge wat deur God bepaal is. ${ }^{2}$ ) In die sigbare Kerk is daar baie hipokriete wat uitwendig wel tot die Kerk behoort maar wesenlik daar geen deel van uitmaak nie. Dit is egter allen aan God bekend wie werklik en wesenlik tot die Kerk behoort; ons kan dan ook nie uitmaak watter mense die ware lede van die Kerk is en watter die hipokriete nie. Hierdie ware Kerk van God, die vergadering van sy volk, is oral te vinde waar sy Woord reg gepreek en aangehoor word en waar die sakramente bedien word soos dit deur Christus ingestel is ${ }^{3}$ ), en dit vorm die twee kenmerke waaraan die Kerk geken word.

Die Kerk is soos 'n dorsvloer waarop die koring gedors is maar nog onder die kaf verborge lê totdat dit met 'n gaffel en deur 'n sif gesuiwer is en die koring dan in die pakhuis gebring word. En as die Heer verklaar dat die Kerk tot op die oordeelsdag hierdie kwaad in haar sal dra en belas sal wees met die vermenging van die sondiges, dan is dit tevergeefs om 'n Kerk te soek wat met geen vlek besoedel en bespat. is nie. $\left.{ }^{4}\right)$ Mens mag jou dan ook in geen geval van die Kerk afskei nie en dit is duiwelse geeste wat soek om die Kerk te verskeur. En dan beroep Calvyn hom op die Skrif om sy opvatting dat die mens jou nie van die Kerk mag afskei nie, mee te staaf. Om die belangrikheid word hier twee uitvoerige uitsprake volledig weergegee:

Maar, sê die mense wat 'n suiwer Kerk wil hê, dit is iets onverdraagliks dat die sonde en gebreke oral so heerskappy voer en in swang is. Maar die gevoelens van die Apostels is hieroor

1) Institutio Christianae Religionis 1559, IV: 1, 4.

2) Inst. IV: 1, 5.

) Inst. IV : 1, 9.

4) Inst. IV : 1, 13. 
duidelik. Die getal van hulle wat gedwaal het, was in die gemeente van Korinte nie klein nie, ja dit het min geskeel of die hele liggaam was met dwaling besmet. Daar was nie net een soort van sonde nie, maar baie. Dit was ook nie ligte oortredings nie, maar sommige was gruwelike sondes. Daar was nie alleen 'n bederf in die sedes nie, maar ook in die leer. En wat het die Heilige Apostel wat die werktuig van die Heilige Gees was, deur wie se getuienis die Kerk staan of val, gedoen? Het hy probeer om 'n skeiding tussen hom en die gemeente te maak? Het hy haar uit die koninkryk van Christus gewerp? Het hy haar met die laaste bliksem van vervloeking geslaan? Hy het nie alleen niks van al hierdie dinge gedoen nie, maar hy erken en verklaar dat sy 'n gemeente van Christus en 'n gemeenskap van die heiliges is. As daar onder die Korinthiërs 'n kerk gebly het terwyl daar warm twiste was, partyskappe en jaloesië, gekyf russies en gierigheid, waar misdaad wat selfs in die oë van die heidene gruwelik en verfoeilik was, openlik toegelaat was, terwyl die naam van Paulus wat hulle as ' $n$ vader moes geëer het ligvaardiglik bespot was,; terwyl sommige oor die opstanding uit die dode gelag het hoewel die wegneming van hierdie geloofstuk die vernietiging van die hele Evangelie is; terwyl die gawe Gods nie tot liefde gebruik was nie maar tot eergierigheid misbruik was, terwyl baie dinge onbetaamlik en onwelvoeglik gedoen was - as daar onder die Korintiërs 'n Kerk gebly het omdat die bediening van die Woord en die Sakramente nie daar verwerp is nie, wie sou dan die naam van Kerk aan sulke vergaderings durf ontneem waar die tiende deel van hierdie gebreke nie gevind word nie? Hulle wat met so 'n groot driestheid teen die gemeentes van ons tyd raas en tekeer gaan, wat sou hulle, vra ek, met die Galate gedoen het wat byna van die Evangelie afgewyk het, maar by wie hierdie Apostel tog nog gemeentes gevind het? ${ }^{5}$ )

En dan wys Calvyn op die belofte Gods wat Hy met sy verbond bevestig het, dat Hy Sy gemeente altyd sal bewaar, ook in tye van die grootste afval. $\mathrm{Al}$ is die koring ook nog so weinig in verhouding met die kaf, dit bly Gods koringmied en is nie 'n kafmied nie. Die bedorwe gemeente bly Gods Kerk.

Christus self, die Apostels en byna al die Profete het ons hiervan 'n voorbeeld gegee. Die beskrywings waarmee Jesaja Jeremia, Joël, Habakuk en andere die gebreke van die Kerk van Jerusalem beween, is gruwelik. Alles was onder die gewone mense, onder die owerheid en onder die priesters so totaal

5) Inst. IV: 1, 14. 
verdorwe dat Jesaja hom nie ontsien het nie om Jerusalem op een lyn met Sodom en Gomorra te stel. Die godsdiens was eensdeels verag en anderdeels besmet. In verband met die sedes word oral van diefstalle, rowerye, trouelooshede, moorde en derglike slegte dade verhaal. En tog het die Profete geen nuwe kerke opgerig nie, of nuwe altare gebou waarop hulle self afsonderlike offerande kon offer. Maar al was die mense ook so, tog het hulle daaraan gedink en onthou dat die Heer Sy Woord onder hulle toebetrou het en die eredienste ingestel het waardeur hy aldaar gedien wou wees, en so het hulle in die midde van die vergadering van die goddeloses tog rein hande tot Hom opgehef. Maar voorwaar, as hulle sou gemeen het dat hulle daardeur ook maar in die minste verontrein sou word, so sou hulle liewers honderd dode wou sterf dan om hulle daartoe te laat meesleep. Daar was dan ook niks anders wat hulle verhinder en weerhou het om hulle van die genoemde Kerk af te skei dan die begeerte wat hul gehad het om die eenheid te bewaar. As die heilige Profete daar dan 'n gewetensbeswaar van gemaak het om hul self van weë die vele en baie groot booshede, nie van een of twee maar byna van die hele volk, van die Kerk af te skei, dan matig ons ons te veel aan as ons ons dadelik van die gemeenskap van die Kerk durf onttrek waar die sedes en doen-en-late van elkeen nie met onse gevoelens en opvatting of ook met die Christelike bekentenis en belydenis ooreenkom nie. ${ }^{6}$ )

En tydens Christus en die Apostels was dit nie anders nie. Die grenselose goddeloosheid van die Fariseërs en die bandelose lewenswyse wat in daardie dae oral die oorhand gehad het, het nie verhinder dat Jesus en die Apostels saam met die volk aan die openbare godsdiensplegtighede in die tempel deelgeneem het nie. En daarom sê Cyprianus tereg:

Hoewel daar onkruid en onreine vate in die Kerk gesien word. so is dit nog geen rede vir ons om van die Kerk af te skei nie en ons moet alleen arbei om self koring te wees en ons moet kragte aanwend en soveel as moontlik is daarna strewe om 'n goue of silwer vat te wees. Dit kom alleen aan die Heer toe aan wie 'n yster roede gegee is, om die erde vate te verbreek. En niemand mag hom dan ook toeëien wat alleen aan die Seun toekom, asof hy instaat is om die dorsvloer te wan en die graan uit te suiwer en al die onkruid deur sy menslike oordeel uit te trek en te skei. Soiets is 'n hovaardige hardnekkigheid en 'n heiligskendende vermetelheid wat uit die slegte hartstog kom. ${ }^{\text {') }}$

6) Inst. IV : 1, 18.

7) Inst. IV : 1, 19. 
Daar was soms hele gemeentes wat met swaar sondes belaai was, maar Paulus self wou liewer op barmhartige wyse red as om te vervloek. Die afvalligheid van die Galate was nie 'n geringe sonde nie; die Korinthiërs het nog groter skuld gehad, maar hulle is tog nie van Gods barmhartigheid uitgesluit nie. ${ }^{8}$ )

Calvyn staaf sy gevoelens dat mens hom nie van die Kerk mag afskei nie, ook met voorbeelde uit die kerkgeskiedenis. So gee hy die volgende aanhaling uit wat Augustinus teen die Donatiste geskryf het wat hulle in Noord Afrika van die Kerk afgeskei het omdat die kerklike tug volgens hulle nie streng genoeg was nie:

As die gewone lede sien dat die kerkraad die sonde en gebreke nie ywerig genoeg bestraf nie, mag hulle hul daarom nog nie van die Kerk afskei nie. Netsomin mag die herders self as hulle al die dinge wat krom en gebrekkig is nie na wens kan herstel en verbeter nie, hulle diens neerlê of deur ' $n$ buitengewone strengheid die hele Kerk in beroering bring. Iedereen moet deur berisping verbeter wat hy kan, en wat hy nie kan verbeter nie, moet hy met die band van die vrede uitsluit; en wat hy nie sonder om die band van die vrede te verbreek kan uitsluit nie, moet hy afkeur, en verdra.

En dan besluit hy met die woorde van Cyprianus :

Laat die mens daarom barmhartiglik verbeter wat hy kan, maar wat hy nie kan nie met berusting verdra en met liefde beklaag en beween. ${ }^{9}$ )

Calvyn wys verder op die vermaning van Augustinus om, as die verdorwenheid en besmetting onder die massa verbrei is, in die gestrengheid van die tug barmhartig te wees. Die beraadslagings om van die Kerk af te skei is ydel, skadelik en heiligskennend.

Hierdie opvattings van Calvyn wat in sy Institusie neergelê is, is artikels XXVII en XXVII van die Nederlandse Geloofsbelydenis beliggaam :

\section{XXVII.}

Oor die Algemene Christelike Kerk.

Ons glo en bely $n$ enige katolieke of algemene Kerk wat 'n heilige vergadering is van die ware gelowiges in Christus wat hulle hele saligheid in Jesus Christus verwag, omdat hulle gewas is deur sy bloed en geheilig en verseël deur die Heilige Gees. Hierdie Kerk was daar van die begin van die wêreld af

8) Inst. IV: 1, 27.

9) Inst. IV: 12, 11. 
en sal daar wees tot aan die einde toe, soos daaruit blyk dat Christus 'n ewige Koning is wat nie sonder onderdane kan wees nie. En hierdie heilige Kerk word deur God bewaar of of in standgehou teen die woede van die hele wêreld, alhoewel dit somtyds 'n tyd lank baie klein is, en in die oë van die mense skynbaar tot niet geraak het. So het die Heer vir Hom gedurende die gevaarlike tyd onder Agab sewe-duisend mense bewaar wat hulle knieë voor Baäl nie gebuig het nie. Bowendien is hierdie heilige Kerk nie geleë in, gebonde aan of bepaal tot 'n sekere plek of tot sekere persone nie, maar dit is versprei en verstrooi oor die hele wêreld; nogtans is dit saamgevoeg en verenig met hart en wil in een en dieselfde Gees, deur die krag van die geloof.

\section{XXVIII.}

\section{Dat Iedereen Skuldig is om Hom by die Ware Kerk te Voeg.}

Ons glo dat, aangesien hierdie heilige vergadering 'n versameling is van die wat gered word en daarbuite geen saligheid is nie, dat niemand, van watter rang of kwaliteit hy ook al mag wees, hom op homself behoort te hou en op sy eie persoon te staan nie, maar dat hulle almal verplig is om hulle daarby te voeg en daarmee te verenig, om die enigheid van die Kerk te bewaar, om hulleself aan sy onderwys en tug te onderwerp. hulle nek onder die juk van Jesus Christus te buig, en die opbouing van die broeders te dien, na die gawes wat God hulle geskenk het as onderlinge lidmate van een selfde liggaam. En om dit des te beter te kan onderhou is dit die plig van alle gelowiges, volgens die Woord van God, om hulle af te skei van diegene wat nie tot die Kerk behoort nie, en hulle te voeg by hierdie vergadering, op watter plek God dit ook al gevestig het, al sou ook die owerhede en verordeninge van Vorste daar teen wees en al sou die dood of enige lyfstraf daaraan verbonde wees. Daarom handel almal wat hulle van die ware Kerk afskei of daarby nie aansluit nie, teen die ordinansie van God.

Teenoor die Ware Kerk waarbuite daar geen saligheid is nie en waarvan Christus die Hoof is, stel die Ned. Gel. Belydenis die Valse Kerk. Hierdie Kerk is in onversoenbare teenstelling met die Ware Kerk. Die Valse Kerk behoort tot die Ryk van die Satan en die Antichris is die Hoof daarvan en daarin is geen saligheid te vinde nie. Dit is die sigbare gestalte van die Ryk van die Duiwel. In Artikel XXIX van die Nederlandse Geloofsbelydenis word vier kenmerke genoem waaraan die Valse Kerk geken kan word: 
Dit skryf aan homself en sy ordinansies meer mag en gesag toe as aan die Woord van God en wil hom aan die juk van Christus nie onderwerp nie; dit bedien die Sakramente nie soos Christus dit in sy Woord verorden het nie, maar neem daarvan af en voeg daaraan toe na sy goeddunke. Dit is meer op mense as.op Christus gegrond en dit vervolg diegene wat heilig lewe na die Woord van God en wat hom oor sy gebreke, gierigheid en afgoderye bestraf.

Met hierdie vier kenmerke word baie duidelik op die Roomse Kerk gedoel. En tog het die Reformatore daarvoor teruggedeins om die Roomse Kerk die Valse Kerk te noem en dit also met die Ryk van die Antichris te vereenselwig. Die doop van die Roomse Kerk is as 'n Christelike doop erken en die herdoop is veroordeel. Vir soiets gruweliks om 'n Kerk 'n Valse Kerk te noem en daarmee al sy lede na die hel en verdoemenis te derigeer, het hulle teruggedeins. Die verste wat gegaan is, is om die biskop van Rome in sy persoon die Antichris te noem soos deur die Sinode van die Franse Kerk wat in 1603 te Gap gehou is, in 'n artikel neergelê is wat in die Geloofsbelydenis gevoeg moes word en wat as volg gelui het:

Aangesien die Biskop van Rome hom self in die Christenheid ' $n$ monargie opgerig het, hom self die oorheersing oor alle Kerke en herders toegeëien het; en hom so verhef as om hom self God te noem, hom te laat aanbid en alle mag in hemel en op aarde toe te skryf; oor alle kerklike sake na sy eie wil te beskik; Geloofsartikels te bepaal; die Heilige Skrif na die goeddunke met gesag te beklee en uit te lê, met die siele en hul saligheid handel te dryf; dispensasie van beloftes en ede te gee; ' $n$ nuwe diens van God op te rig; en in verband met die regering die gesag van die owerheid met voete te vertree; koninkryke af te neem, weg te gee en te verander; so glo en beskou ons dat hy eintlik die Antichris en die seun van die verderf is soos in Gods Woord voorspel is, en die hoer wat in skarlaken geklee is en wat in die groot stad op die sewe berge sit en wat sy heerskappy oor die konings van die aarde uitoefen. En ons verwag dat die Heer soos $\mathrm{Hy}$ beloof en begin het om hom met die Gees van sy mond te verslaan, hom eindelik deur die sekerheid van sy toekoms sal vernietig. ${ }^{10}$ )

\section{Die Hervormde Kerk as Valse Kerk Uitgemaak.}

In Suid-Afrika vind ons egter dat die Sinode van die Gereformeerde Kerk in 1869 in 'n "Openbare Verklaring" in Potchefstroom gekonstateer het dat die Nederduitsch Hervormde

10) E. Benort: Historie der Geref Kerk van Vrankryk (1696) Deel I. bls. 245. 
Kerk hier te lande 'n ",bedorwe kerkgemeenskap", ja nog meer, ",de valsche Kerk" is en dat die Gereformeerde Kerk hom om hierdie rede daarvan afgeskei het. Hierdie verklaring verdien 'n historiese toeligting.

In die Noordelike dele van die Kaapkolonie, in die Oranje Vrystaat en in Transvaal was daar ' $n$ honderd jaar en langer gelede baie mense wat besware teen die gebruik van die Evangelische Gezangen in die openbare godsdiensoefening gehad het. Oor hierdie Gesange-twiste word hier nie gehandel nie. Dit is elders beskryf. ") Na die koms van ds. Postma in Transvaal is die Hervormde Kerk voor die beslissende keuse gestel om die gebruik van die Gesange af te skaf of om 'n gevaar van 'n kerkskeuring te loop. Die Algemene Kerkvergadering het op 11 Januarie 1859 met 19 teen 3 stemme besluit ,dat de kerklijke inrichting, zooals blijven bestaan en gehandhaafd worden". Ds. Postma het deur hierdie besluit nie kans gesien om hom ",volgens Gods Woord" en ",met het oog op de geopenbaarde gevoelens" in die Hervormde Kerk beroepbaar te stel nie en het toe van die Vergadering afskeid geneem. Dit het op vredeliewende wyse geskied. Ds. Postma het sy gevoelens op skrif gestel en dit in die Vergadering voorgelees. Hierin kom onder andere die volgende woorde voor:

$\mathrm{Bij}$ deze gelegenheid betuig ik allen die mij hunne vriendschap bewezen hebben, mijnen hartelijken dank. Tevens betuig ik mijnen hartelijken dank aan Leraar en Kerkeraden, die mij met hun vertrouwen hebben begiftigd, en niet minder betuig ik dit aan die Burgerlijke Autoriteiten die mij met zooveel erkentenis hebben vereerd.

En van harte reik ik ulieden, in overeenstemming van het waar geloof, de broederhand, en hoop door Gods genade dit altoos mijnerzijds met der daad te betoonen.

Hierin het ds. Postma dus skriftelik verklaar dat daar tussen hom en die Hervormde Kerk 'n "overeenstemming van het waar geloof" was en dit met sy broederhand bevestig. Die antwoord van die Algemene Kerkvergadering hierop was dat dit ook ,.overtuigd was, dat in het punt des geloofs geen verschil bestond" en was ,,algemeen van gevoelen, dat het punt der Evangelische Gezangen geen hinderpaal zou zijn om elkander de broederhand der gemeenschap toe te reiken" wat dan ook werklik ",niet zonder blijken van gevoel en droefheid" gedoen is.

Die eerste ouderlinge en diakens van die mense wat hul afgeskei het, is op 11 Februarie 1859 onder leiding van ds. Postma gekies. Hulle is nog op dieselfde dag in hul amp bevestig en het onmiddellik

11) S. P. Engelbrecht: Geskiedenis van die Ned. Herv. Kerk, bls. 145-169. S. P. Engelbrecht: Die Ned. Herv. Gem. Rustenburg 1850-1950, bls. 33-48. 
daarna hul eerste kerkraadsvergadering gehou, waarop o.a. besluit is om van die gebeurde aan die Kaapse Kerk en aan die Transgariepse Ring (die Vrystaat) ,behoorlijk kennis te geven, ten einde wij de onderlinge vriendschap moge bevordelijk zijn tusschen de Kerken die met ons dezelfde belijdenis hebben. En zoo spoedig mogelijk zal men dit doen aan de Nederduitsch Hervormde Kerk in dezen lande".

Daar was geen sweem van bitterheid nie, geen wedersydse veroordeling of uitsluiting uit die Koninkryk van God nie; die eenheid in Christus Jesus is beklemtoon. En toe ds. Postma, wat wewenaar was, opnuut in die huwelik getree het, het hy hierdie huwelik op 24 November 1854 deur ds. Van der Hoff in die Hervormde Kerk van Rustenburg laat bevestig. Hy was verdraagsaam waar dit vir hom moontlik was, hoewel vashoudend aan in eenmaal ingenome standpunt. ${ }^{12}$ )

Die Kommissie in Holland wat ds. Postma na Suid-Afrika afgevaardig het, was aanvanklik aarselend teenoor die Afskeiding in Transvaal. Was die Hervormde Kerk hier lande werklik 'n valse Kerk waarvan die Gelowiges hulle moes afskei? Die Kommissie het dan ook op 1 September 1859 aan ds. Postma geskryf en hom reguit gevra waarvoor hy die Ned. Hervormde Kerk dan hou. Ds. Postma het op 3 Desember, dadelik na ontvangs van die brief van die Kommissie uit Holland en nege dae nadat sy huwelik in die Hervormde Kerk bevestig is, hierop geantwoord. In hierdie antwoord was hy dus verplig om die Afskeiding te regverdig, waaruit weer noodwendig gevolg het dat hy die bestaande Kerk in Suid-Afrika so donker moontlik moes skilder. So het hy o.a. aan die Kommissie oor die Hervormde Kerk as volg geskryf :

Vóór haar genomen besluit te Pretoria ${ }^{13}$ ) beschouwde ik haar als de gemeente des Heeren, ziende op haar belijdenis en getuigenis daaromtrent, hoewel zij mij $z w a k$ en donker voorkwam, maar ik heb willen gelooven, zoo lang ik niet anders zag. Maar bij het nemen van dat besluit heb ik gezien, dat de door mij geachte zwakheid een hardnekkig en verkeerd beginsel was, nl. eigengoeddunken boven den Bijbel, hetwelk is tegen den Bijbel. Dit moet echter niet van allen dier zijds gezegd worden, maar dit was en is nog hun heerschend beginsel. Daarom zeide ik in die Vergadaring ,.dat bij zulk een besluit de paus geboren wordt al is hij dan nog maar klein en zwak".

12) Vgl. „Ds. Durk Postma voor sy koms in S.A.", deur S. P. Engelbrecht in Hervormde TeOlOgiese Studies Junie 1949, bls. 145-171. Ds. (later prof.) L. J. DU Plessis sê ten onregte op bls. 215 van die „Gedenkboek der Geref. Kerk in Z.A." (1909) dat ds. Postma in Holland tot die strenge party behoort het. Hy het juis meermale met hierdie party gebots omdat dit so onverdraagsaam was.

13) Nl. die besluit van die Algemene Kerkvergadering van 11 Januarie 1859, bowe vermeld, om die Gesange te bly handhaaf. 
En vermaande met vele woorden en met veel zachtmoedigen ernst, ja met vele langmoedigheid, tegen zulk een doen. Doch vruchteloos. Zoo werd het mij onmogelijk om onder dat besluit - en onder die openbaarwording van den geest der Kerk, onze hulp toe te zeggen of ook in eigen persoon te verleenen. Daarom heb ik ook het uittreden van de broederen onzerzijds voor wettig, eerlijk en pligtmatig kunnen verklaren en mij verpligt gevoeld, door en daartoe opgeroepen, hen als eene Gereformeerde Gemeente te ordenen. De Nederduitsche Hervormde Kerk heeft naderhand wel, op verzoek der Overheid, haar besluit gewijzigd, ${ }^{14}$ ) maar haar beginsel niet verlaten, daarom is het ons nog niet mogelijk geworden, op aanzoek van de Overheid met haar te hereenigen.

Om haar nu echter in statu quo voor eene valsche Kerk te verklaren, daartoe gevoelen wij ons nog niet geroepen.

Gaat zij zoo voort, dan seker zal dat karakter niet uiblijven, maar duidelijk voor den dag treden. Maar nu toonen wij nog maar altoos aan, dat zij dwaalt en waarschuwen voor ergere gevolgen. ${ }^{1 .}$ )

Die Afskeiding het hom ook na ander dele van Suid-Afrika verbrei soos die Vrystaat en die Kaapkolonie, waar daar mense was wat teen die sing van Gesange gekant was. ${ }^{16}$ )

Die kerkraad van die gemeente Reddersburg wat op 17 Mei 1859 deur ds. Postma gestig is, het reeds op 6 Junie besluit om vir die Vrystaat en die Kaapkolonie 'n predikant uit Holland te beroep en

11) Dit was die besluit van die Alg. Kerkvergadering in April 1859 om die sing van die Gesange ,aan de wijsheid en het geweten van elken Leeraar" oor te laat om "daarin te handelen naar zijn geweten met in achtnemen van den toestand der gemeente". Maar volgens ds. Postma het die Hervormde Kerk hiermee sy „verkeerd beginsel nog nie losgelaat nie, dit kor alleen geskied deur die gebruik van die Gesange in die kerkdienste heeltemal af te skaf. Maar dit wou die Algemene Kerkvergadering nie doen nie.

15) Handelingen van de Synode der Christelijke Afgescheidene Gereformeerde Kerk in Nederland, 1860 , bls. 72-73.

19) Ds. T. Hamersma, predikant van die Gereformeerde Gemeente, Colesberg, was 'n voorstander van die "Vrije Lied in die Gereformeerde Kerk". In sy briewe wat in die kerkblad verskyn het en na sy dood in 1943 onder die titel .Van Hart tot Hart" afsonderlik uitgegee is, verhaal hy op bls. 207 hoe op die Sinode van die Gereformeerde Kerk wat in 1927 op Reddersburg gehou is, ook oor die vrye lied gepraat is. Een bejaarde broeder (Ds. L. P. Vorster, wat in Middelburg, Kaapkolonie, gebore was) het taamlik sterk daarteen gepraat. Onder die diskussie was die tyd van sitting verstreke en die voorsitter versoek toe ds. Vorster om 'n versie op te gee en die vergadering met gebed gesluit. Ds. Vorster laat toe sing die laaste versie van die gerymde 'Tien Gebooie. Ds. Hamersma sê hiervan: „Maar daardie versie staan nie in die Bybel nie, nie in Exodus 20 en ook nie in Deuteronomium 5 nie. Toe die predikant dit op die Sinode laat sing het, het hy dus in stryd gehandel met sy eie woorde en sy eie protes teen die vrye lied". 
die uitvoering daarvan aan ds. Postma op te dra, waarop hy namens die gemeente sy vriend. ds. $\mathrm{H}$. de Cock, dosent aan die Teologiese skool te Kampen, beroep het. Dosent De Kock het op 1 September 1859 hierop geantwoord en aan die gemeente geskryf dat:

Daar ik Europa beschouw als een vulkaan die elk ogenblik kan ontbranden, lacht $Z$. Afrika of ook elk land dat buiten alle aanraking met het beeld Nebucadnezer ligt, mij altoos zeer toe, met het oog hierop zou ik dadelijk kunnen en willen zeggen, ik zal tot u.l. overkomen.

Maar daar was 'n paar sake waarvoor hy graag eers meer inligting wou gehad het. Een daarvan was die redes van die afskeiding in die Vrystaat. Dit was vir hom nie duidelik nie. In Transvaal, so het hy geskryf, het die mense hul afgeskei omdat die Algemene Kerkvergadering van die Hervormde Kerk die gebruik van die Gesange in die Kerk nie wou afskaf nie, maar dit bevestig het. Maar die Transvaalse Algemene Kerkvergadering het tog nie in die Vrystaat gesag gehad nie, want daar het die Gemeentes onder die Kaapse Sinode gestaan. Hy het dan ook onomwonde geskryf :

Ik weet geen eene grond waarop zich de afscheiding in den Vrystaat laat verdedigen en moet daarom verzoeken dat mij worden opgegeven

1e. Wat de aanleidende oorzaken zijn van de afscheiding in uwen staat.

2e. Op welke gronden $z$ ij rust.

Die kerkraad het op 14 Januarie 1860 dosent De Cock in 'n brief wat deur ds. Postma opgestel is geantwoord en het goeie verwagtings gehad dat hy na die ontvangs daarvan die beroep na die Vrystaat sou aanneem. Maar dan moes daarin redes opgegee word wat dosent De Cock van die noodsaaklikheid van die Afskeiding sou oortuig. Die volgende redes is toe genoem:

Reeds sinds vele jaren werden wij gekweld met het zingen der Evangelische gezangen, want hoewel de Kerk niet eene wet had die de leeraren volstrekt verpligtte daaruit te laten zingen, werden wij toch door hen en door kerkbesturen zoo behandeld, alsof het laten zingen en het zingen zelve eene gehoorzaamheid was aan Gods Woord en het nalaten eene censurabele zonde, waarom sommigen bepaald onder censuur zijn gezet; ${ }^{17}$ ) anderen de aanneming geweierd zoo zij niet beloofden die mede te zingen, insgelijks werd ook soms de doop geweigerd

17) 'n Noukeurige ondersoek in die betrokke kerklike argiewe het my beslis cortuig dat daar in Suid-Afrika nérens iemand vanweë 'n weiering om Gesange te sing, onder sensuur gestel is nie. Sommige mense het wel gemeen en ook verklaar dat huue gesensureer was; maar hulle moes onder 'n misverstand verkeer het. Vgl. Die Nederduitsch Hervormde Gemeente Rustenburg 1850-1950, deur my self, bls. 33-48. 
van kinderen welker ouders de gezangen niet verkozen mede te zingen.

En ons hart was en bleef toch maar altoos bezwaard over de invoering derzelve in de openbare Godsdienst en ook gevoelden wij nooit een vereeniging met den doorgaande geest. die in de gezegde gezangen heerscht.

Het ontbrak ons echter doorgaans aan bekwaamheid om tegen onze leeraren onze gevoelens te verdedigen. En trad er al eens een bekwame uit ons midden, hij werd niet gehoord; maar veracht en mishandeld. En alhoewel al de leeraren in dezen niet even hard waren, echter was er niet een die ons hierin ter zijde stond, zoodat ons lijden vele jaren $z$ waar was en wij openbaar bij onze tegenparty den scheldnaam van „Doppers" droegen. Aangaande de leer kan men wel niet zeggen zoo vervallen als die van de Herv. Kerk in Nederland volgens hetgeen wij lazen of hoorden, maar toch was ze ons over het geheel te algemeen en de voorname leerstukken ontbraken ons bij de meesten, ja, bij hen die nog al een naam van rechtzinnig hebben, $n l$. de praedestinatie met hetgeen daarmee in verband staat. De bevinding hoorden wij weinig of niet prediken. Zoodat onze ziel altoos hongerig en dorstig bleef, niet bij allen, maar over het geheel genomen.

Wat de kerkregering betreft, onze onkunde verhinderde ons speciaal aan te toonen wat al in die menigte reglementen ongereformeerd was, maar dit zagen en gevoelden wij, dat de kerkregering ons te wereldsch was. Wij werden maar verplicht. omdat de Synode het had besloten, als het maar een reglement was. Er werd minder, of niet gevraagd: Is het naar Gods Woord? Ook niet of zulks voor ons en onze omstandigheden eer schadelijk dan voordeelig was, als de Synode of Ring het maar besloten had, dan moest het maar gehoorzaamd worden. En wij eerbiedigen gaarne onze Geestelijke Herder en Kerkvergaderingen, maar toch niet op Roomsche wijs, om maar te geloven wat de Kerk gelooft.

Wij waren dus altyd onder vrees en zuchting. Vraagden wij naar de oude paden, dit was te vergeefs. Vraagden wij of er dan toch in Nederland geene oud- Gereformeerden meer waren, dan kregen wij van onze leeraren ten antwoord: Ja, er waren nog weinigen die de gezangen niet zongen, maar dat waren $\ldots{ }^{18}$ ) De eigenlijke afscheiding en herstelling naar

18) Van hierdie brief aan dosent De Cock het ek twee afskrifte, een uit die jaar 1860, die ander omstreeks 1880 . In altwee afskrifte is die oorspronklike woord hier weggelaat en deur stippels vervang. 
Dordrechts leer en kerkdienst werd zooveel mogelijk voor ons verborgen gehouden. Slechts een leeraar heeft aan sommigen onzer zoo veel van de waarheid verteld dat wij niet meer van uwe Kerk dien slechten indruk kregen maar veel eer hope koesterden op eene uitkomst. Onze broeder J. J. Venter ${ }^{19}$ ) en een enkele met hem, vernamen toevallig, naar den mensch gesproken, van een particulier man uit Nederland meer van die zaak.

$\mathrm{Nu}$ begon men te werken. Men zocht, maar door misleiding werden wij niet naar het rechte kantoor gewezen. Sommigen onzer hadden reeds de kerkgemeenschap bedankt, hopende de Heer zal uitkomst geven.

En zie, boven bidden en danken baant God zelf den weg! Uwe Kerk wordt opgewekt om te denken aan de Republiek; een afgevaardigde Herder en Leeraar word derwaarts gezonden. En wij weten en getuigen dat $Z$. Ew. daar genoodzaakt was alzoo te handelen als hij heeft gehandeld. Hij heeft daar dus de Gereformeerde Kerk hersticht naar het Woord des Heeren. De Heer J. J. Venter, die aan Br. v. Andel geschreven had om eene leeraar uit uwe Kerk, wordt door Z.ED. op hem gewezen en Z.E.W. zelf van wege de Syn. Com. verzocht ook die zaak te onderzoeken en daarvan rapport te zenden naar dien men buiten zijn rapport niet aan dat verlangen kon voldoen.

19) Jacobus Johannes Venter (1814-1889) was as ouderling een van die ondertekenaars van hierdie brief. Hy was 'n baie interessante persoon in die Vrystaat waar hy meermale as vise-president opgetree het. Kerklik het hy hom reeds in 1858 in Bloemfontein van die gemeente van ds. A. Murray afgeskei. Die briewe wat hy toe na Holland geskryf het, hoop ons later te publiseer. Hy het op die „bevindelikheid" baie nadruk gelê en was sterk piëtisties. Mens moes veral die genade Gods persoonlik in die siel ondervind. J. M. Orpen vermeld op bls. 347-348 van sy Reminiscences die volgende gesprek wat in 1854 tussen hom en Venter plaasgevind het: One Sunday Jacobus Venter had a long chat with me. He found that I had a moderately good knowledge of the Bible and of Christian doctrine. Presently he went further and asked me if I had ever become engaged in a real conflict with the Devil in person. I said no, I had never had that remarkable experience. "Ah", said he, "that is the way it goes with a Christian who is walking in a fancied security. The Devil lets him go his own way, but when he preceives a really experienced Christian he attacks him with all his might. I have been engaged in several personal conflicts with the Devil". Toe hy hom in 1858 van die Ned. Gereformeerde Kerk afgeskei het en ds. Murray as leraar en die kerkraad van Bloemfontein bedank het, het hy op 8 Februarie persoonlik in die kerkraad verskyn en 'n brief oorhandig ,inhoudende de opgaaf van redenen voor het bedanken van Leeraar en kerkeraaad. $\mathrm{Z}_{\mathrm{ij}}$ waren behalve het verschil omtrent de Evang. Gezangen; Eerst dat Bedestonden in de kerk werden toegelaten; ten tweede: Het gebruik van kruistafels bij de Avondsmaalbediening; ten derde: De nieuwe vorm van het Huwelijk; ten vierde: De wyijze waarop jonge Ledematen in het geloof werden bevestigd: ten vijfde: Het verklaren van het Evangelie in de Kerk alhier". Later kon hy met ds. Postma ook nie meer klaarkom nie en het in 1875 n boekie oor sy moeilikheid uitgegee onder die titel : "Wat is Waarheid?" Dit is hoogs seldsaam. 'n Fotografiese kopie is in my besit. "Hy het hom 'n paar jaar later weer van die Gereformeerde Kerk afgeskei. 
De Heer J. J. Venter verzocht derhalve den afgevaardigden uwer Kerk tot ons over te komen en haalt hem zelfs op. $\mathrm{Nu}$ hooren wij uit zijnen mond de waarheid aangaande uwe Kerk in Nederland, gestaafd met publieke schriften. $\mathrm{Nu}_{\mathrm{u}}$ verdwijnt alle donkerheid en alle twijfel wordt opgeheven en wij zien nu duidelik uit schriften en daden, dat de Kerk als Kerk beschouwd in de welke wij nu zoolang vruchteloos hadden gestreden, het houdt met de valsche kerk in Nederland en de ware Gereformeerde Kerk aldaar miskent en veracht. En $\mathrm{nu}$ God door zijne ondoorgrondelijke voorzienigheid boven bidden en danken in de Z.A Republiek de ware gereformeerde Kerk weer heeft te voorschijn geroepen, durven wij niet langer blijven in die Kerkgemeenschap die haar miskent; maar gevoelen ons van God geroepen met die miskende en toch ware gereformeerde Kerk in gemeenschap te staan, hetwelk wij dan ook gezocht en door genade verkregen h"bben. Naardien de afgevaardigde uwer Kerk, nu herder en leeraar van de gereformeerde Kerk in de Z.A. Republiek, zich met zijne algemene kerkverg. verplicht gevoeld heeft aan onze begeerten gevolg te moeten geven, nadat $z \mathrm{ij}$ bij ons alles wel hadden onderzocht, hetwelk echter meer een behoefte was voor den afgevaardigde leeraar Postma, dan voor die broeders van daar, want zij hebben met ons diezelfde ervaring van uit de Kaap Kolonie. Sommigen derzelven zijn zelfs met die hope geëmigreerd, dat zij daar nog meer mogelijkheid zouden vinden voor het herkrijgen van de ware gereformeerde Kerk, dan onder de alles beheerschende Synode der Kaapsche Kerk.

Wij hebben ons dus afgescheiden van die Kerk, die zich wel gereformeerd noemt, maar intusschen ver is afgeweken van de ware gereformeerde leer en dienst, terwijl zij het houdt met de valsche Kerk in Nederland en de ware gereformeerde Kerk aldaar miskent, en hebben ons aangesloten bij die miskende en toch ware gereformeerde Kerk, nu ook door Gods ondoorgrondelijke voorzienigheid in Zuid-Afrika herrezen. Als eene zoodanige gemeente hebben wij ons hier laten ordenen en worden als zoodanig reeds door den Staat erkend. En hebben dus naar het voorbeeld der Christ. afgescheiden gereformeerde Kerk in Nederland het Evangelisch gezangeboek afgeschaft, alsmede het boek der kerklijke reglementen, en de kerkorde van Dordregt 1618 en 1619 zoveel mogelijk gevolgd.

En hiermede meenen wij meteen aan uw verzoek voldaan te hebben, nl. een kort verslag van den toestand der Kerk, van de welke wij ons hebben afgescheiden. Uit al het opgenoemde, zoo kort mogelijk, kan U.E.W. zien dat wij sinds vele jaren 
zeer bezwaard en zuchtend verkeerd hebben in de Kerk waar het liberalisme ook al op alles eenen geweldigen invloed uitoefende, waarom wij dorstend uitzagen naar eene uitkomst, die wij tevergeefs zochten, naardien de waarheid aangaande uwe Kerk ons verborgen werd gehouden en wij aan de andere zijde misleid werden overmits ons niet de rechte personen werden aangewezen, maar nu heeft God ons het licht in de duisternis doen opgaan en alzoo onze zuchtingen verhoord. De komst van Postma is dus niet de oorzaak onzer afscheiding, maar slechts eene vervulling eener langbestaande behoefte.

Dosent De Cock het egter nie sy weg oopgesien om die beroep aan te neem nie. Burgersdorp het 'n beroep uitgebring op ds. J. W. te Bokkel, maar hy het ook bedank. ${ }^{20}$ )

Nieteenstaande die uitvoerige antwoord van ds. Postma aan die Sinodale Kommissie op 3 Desember 1859 en die bowegemelde uitvoerige skrywe van die kerkraad van Reddersburg op 14 Junie 1860 aan dosent De Cock, het die Sinode van die Afgeskeie Kerk in Holland tog aarselend teenoor die afskeiding in Suid-Afrika bly staan en op 16 Junie 1860 die volgende besluit geneem:

Aangezien de Synode door het ongenoegzame der inlichtingen, niet in staat is gesteld om te beoordelen of de afscheiding in Z.-Afrika met Art. 28 en 29 onze geloofsbelijdenis overeenkomt, daarom kan zij betreffende de scheiding geen beslissend oordeel uitspreken. Wanneer derhalve Leeraars daarheen beroepen worden, wordt het hun zelven overgelaten om na ernstig beraad te handelen, zoo als zulks naar hun oordeel het meest tot bevordering van Gods Koninkrijk kan strekken.

Ook het dieselfde Sinode op 18 Junie sy ,afkeuring" te kenne gegee oor die veranderings wat ds. Postma in 1859 in die Dordtse Kerkorde aangebring het toe hy 'n eie kerkorde opgestel het waarin hy die Dordtse ,,zooveel mogelijk" gevolg het. ${ }^{-1}$ )

20) 'n Kopie van die brief van sy bedanking is op bls. 144-147 van die Almanak van die Gereformeerde Kerk van 1929 afgedruk. Maar dit is in baie slegte kopie wat vol spelfoute is. Dit moet deur iemand gemaak wees wat baie ongeletterd was. Soos dit daar in die Almanak afgedruk is, wek dit die indruk dat ds. Te Bokkel in ongeletterde man was. Maar hoewel hy nie iemand van veel studie was nie, ongeletterd was hy in elk geval nie. Dit is jammer dat die persoon wat hierdie slegte kopie laat afdruk het dit nie nader toegelig het om misverstand te voorkom nie.

21) Hierdie veranderde Dordtse Kerkorde is op 10 Feb. 1859 te Rustenburg vir Transvaal goedgekeur, op 6 Junie 1859 op Reddersburg vir die Vrystaat en op 23 Januarie 1860 te Roosterkoek vir die Kaapkolonie. Op die eerste Sinode van die Geref. Kerk van 1862. het hierdie Kerkorde groot moeilikheid veroorsaak en omdat die mense die onveranderde Dortse Kerkorde wou behou, het die Sinode hierdie gewysigde een verwerp. 
Daar het verdere korrespondensie tussen ds. Postma en die Sinodale Kommissie wat hom uitgestuur het, plaasgevind, maar die Sinode het aarselend gebly en op 14 Augustus 1863 besluit:

De Synode kan de afscheiding in Zuid-Afrika niet veroordelen, doch acht zich evemin geroepen haar goed te keuren en wil gaarne aan het verzoek van de Gereformeerde Kerk voldoen. ${ }^{29}$ ) Wat Ds. Postma betreft, verklaart de Synode dat zij Z.Ew. thans niet meer als zendeling ${ }^{23}$ ) kan beschouwen, doch wil $Z$. Eerw. niet veroordeelen in den weg, waarin hij door de Voorzienigheid is geleid.

De gewijzigde toestand brengt echter de Kerk van ZuidAfrika onder de roeping de gelden, door onze Kerk voor de zending van Ds. Postma betaald, te restitueren, ten einde de gelden bepaald voor de Heidenen bijeen gezameld, tot dat einde door ons besteed mogen worden.

Hierdie besluit is op bls. 135 van die „Gereformeerde Kerkregering of Handboek voor Leeraars en Kerkeraadsleden" afgedruk wat in 1868 deur dosent De Cock uitgegee is. Die Gereformeerde Kerk in Suid-Afrika was as vanselfsprekend teleurgesteld dat hierdie weiering om die afskeiding hier as wettig te erken ook nog boonop in hierdie Handboek wat die Gereformeerdes in Holland as leidraad vir kerkregering moes gebruik, afgedruk is, asook die onvriendelike verpligting wat op die Gereformeerde Kerk in Suid-Afrika gelê is om die geld wat gebruik is om ds. Postma uit te stuur, terug te betaal omdat ds. Postma hier 'n kerklike afskeiding bevorder het wat nie deel van sy opdrag was nie.

Ds. Postma het ingesien dat dit vir sy Kerk van lewensbelang was om die afgeskeie Kerk in Nederland tot ander gedagtes te bring en dat die afgeskeie Kerk in Suid-Afrika in Nederland erken sou word. Daarom het hy op 22 Mei 1869 in die Sinode wat toe in Potchefstroom vergader het, voorgestel dat 'n kommissie benoem sou word om 'n verklaring te gee oor die oorsake van die afskeiding van die Ned. Hervormde en van die Ned. Gereformeerde Kerke. Die voorstel is aangeneem en die kommissie is benoem en na in pouse, nog dieselfde voormiddag, het dit ' $n$ uitvoerige verklaring ingedien wat met algemene stemme aangeneem is as uitdrukking van die gevoelens van die Sinode. Dit is duidelik dat ds. Postma hierdie verklaring reeds klaar opgestel gehad het toe hy voorgestel het om in kommissie daarvoor te benoem.

22) Dit is nie duidelik watter Kerk hier met ..Gereformeerde Kerk" bedoel word nie, die Ned. Gereformeerde of die (enkel) Gereformeerde: en ook nie watter "verzoek". Die Sinode van die Gereformeerde Kerk wat in 1869 in Potchefstroom gehou is, het dit ook nie verstaan nie.

23) Dit wil sê, afgevaardigde na Suid-Afrika. 
Hierdie verklaring was die laaste maar ook tewens in kragtige poging om die Gereformeerde Kerk in Nederland te beweeg om die afskeiding in Suid-Afrika te erken. En om die afskeiding te regverdig is die Ned. Hervormde sowel as die Ned. Gereformeerde Kerk met swart kleure afgeskilder. Van die Nederduitsch Hervormde Kerk is selfs verklaar dat dit 'n ,,bedorven kerkgemeenschap" is, ja, ,,die valsche Kerk". In "n begeleidende skrywe het die Sinode daaroor gekla dat die onvriendelike besluit van die Afgeskeie Kerk van Holland van 1863 in die "Gereformeerde Kerkregering of Handboek" van dosent De Cock opgeneem is; en gewys op die eienaardige verwagting dat die Afgeskeie Kerk van Suid-Afrika die geld wat vir die reiskoste van ds. Postma gebruik is, moet terugbetaal; en verder is gekla oor die .,verkoeling in de ware broederlijke gemeenschapsoefening" wat daar tussen die Nederlandse en Suid-Afrikaanse Afgeskeie Kerke gekom het.

Hierdie ,verklaring" het die gewenste uitwerking gehad. Dit is in 1872 saam met die begeleidende skrywe deur die Hollandse Sinode behandel, waarop besluit is om die Gereformeerde Kerk in SuidAfrika ,als eene Zusterkerk" te erken, terwyl die besluite oor die terugbetaling van die reiskoste van ds. Postma ,vervallen zijn verklaard, en alzoo de bestaande grieve is opgeheven".

Offisiëel was die Hervormde Kerk voortaan vir die Gereformeerde Kerk die valse Kerk, die Kerk van die Antichris, waarvan die lede buite die ware Kerk staan waar daar geen saligheid is nie. Maar dit was 'n geleentheidsverklaring wat alleen as doel had om die Gereformeerde Kerk in Holland te beweeg om die afskeiding in SuidAfrika goed te keur en die Gereformeerde Kerk te erken. In die kerklike praktyk is van hierdie verklaring nie veel gemerk nie. Die doop wat in die ,valse" Hervormde Kerk bedien is en wat dus ' $n$ valse doop moes wees, is tog erken en diegene wat na hierdie verklaring uit die Hervormde Kerk na die Gereformeerde Kerk oorgegaan het, is nie oorgedoop nie. Die verhouding tussen dit twee Kerke het in die loop van die jare beter geword, hoewel hierdie verklaring waarin die Hervormde Kerk as valse Kerk veroordeel is, tot ongeveer 1931 gereeld as bylae agter die Dordtse Kerkorde afgedruk is. Vanaf daardie jaar is dit weggelaat maar die Hervormde Kerk het tog nog offisiëel die valse Kerk gebly.

Die teenstrydigheid in hierdie houding het meer en meer opgeval en so het die klassis Potchefstroom van die Gereformeerde Kerk die volgende beskrywingspunt na die Partikuliere Sinode gestuur wat dit op sy beurt weer na die Sinode van 1939 deurgestuur het:

Gesien die volgende verskynsels in ons kerklike lewe:

a) Dat daar prakties in sekere mate van korrespondensie be- 
staan tussen Geref. Kerke enersyds en die Ned. Geref. en die Ned. Herv. Kerke andersyds, soos blyk uit verskillende kerklike handelinge;

b) dat sommige kerkrade in hierdie korrespondensie miskien verder gaan as andere en dat daar as 'n gevolg hiervan allerlei teenstrydige praktyke in die Geref. Gemeentes gevolg word;

c) dat ook die Generale Sinode reeds deur die benoeming van in deputaat vir korrespondensie met binnelandse kerke en deputate op 'n interkerklike kommissie 'n sekere mate van korrespondensie daargestel het;

So versoek die Klassis Potchefstroom die Part. Sinode, om die vraagstuk van erkenning van en korrespondensie met die ander twee genoemde kerke onder die oë te sien en te bepaal in hoeverre die praktiese, daadwerklike toestand ook offisiëel beslag mag kry en hierin leiding aan die Kerkrade te gee, om also te voorkom dat allerlei teenstrydighede onder ons burgerreg verkry.

Die Sinode het 'n ,Kommissie van praeadvies" benoem om op die volgende Sinode hieroor te rapporteer. Op die Sinode wat hierop in 1942 vergader het, is toe die volgende hieroor gerapporteer:

In die praktyk het die Hollandse Kerke mekaar reeds as Christelike Kerke erken deur noue samewerking in baie sake, soos bv. Bybelvertaling, Psalmberyming, lidmaatskap, ens. Die Algemene Sinode word nou net gevra om aangesien die Geref. Kerk reeds in die praktyk bewys het dat hy beide die Ned. Geref. Kerk en die Ned. Hervormde Kerk erken as Christelike kerke, te verklaar, dat die Geref. Kerk graag broederlike verhouding en hartelike samewerking wil onderhou sowel $m=t$ die Ned. Geref. as met die Ned. Herv. Kerke, veral deur sy deputate op die Interkerklike Kommissie en deur 'n tweede deputaatskap, wat saam met die lede van die I.K. sake van gemeenskaplike belang met die susterkerk kan bespreek.

Die Sinode het hieroor as volg besluit :

In verband met $\mathrm{C}(1)$, naamlik rapport insake erkenning van en korrespondensie met Ned. Ger. en Ned. Herv. Kerke, keur die Sinode goed wat gedoen is, die broeders word bedank vir hulle werk en die deputaatskap word herbenoem.

In werklikheid het die Sinode oor die saak waaroor dit gaan feitlik niks besluit nie. Die kommissie het die Sinode gevra om te verklaar dat die Geref. Kerk graag broederlike verhouding en hartlike samewerking wil onderhou, sowel met die Ned. Geref. as met die Ned. Herv. Kerke veral deur sy deputate op die Interkerklike Kommissie 
en deur 'n tweede deputaatskap, wat saam met die lede van die I.K. sake van gemzenskaplike belang met die susterkerke kan bespreek.

Maar die Sinode het net die werk wat die Kommissie gedoen het. goedgekeur sonder om die gevraagde verklaring te doen. Dit is begryplik, die Sinode kon nie verder gaan nie. As openlik sou verklaar word dat die Hervormde Kerk nie die valse Kerk is nie soos die Sinode van 1869 beweer het, sou daarmee die afskeiding van 1859 veroordeel wees en sou die Geref. Kerk sy eie bestaan moet ophef. Die verklaring van 1869 dat die Hervormde Kerk die valse Kerk is, was enkel en alleen bedoel om die afskeiding in Nederland te regverdig. maar was prakties nooit die oortuiging van die Geref. Kerk nie en vandaar die tweeslagtigheid.

S. P. ENGELBRECHT. 